\title{
STUDENT'S SOCIOAFFECTIVE STRATEGY IN READING
}

\author{
Rosyidah Jayanti Vijaya \\ STMIK Amikom Yogyakarta
}

\begin{abstract}
Informatics grows fast along with articles related to it and the students of STMIK AMIKOM need to have the ability to read comprehensively to deal with her study and work place. This case study is aimed to explore and find the pattern of student's socioaffective strategies in reading and how they are applied. As the socioaffective strategy found, it will be easier for the teachers to provide English reading materials that suit their strategy preferences, more enjoyable for the students, and raise students' awareness of socioaffective strategy. Hopefully, it will lead students to become autonomous in reading, foster their good adjustment in study and work place, bring a broader awareness of socioaffective strategy in reading, and invites further research related to this strategy.

A preliminary observation was taken to choose one Information System student of semester 3, who had just experienced reading class, as this project participant. Data were collected through interviews with 16 indicators of socioaffective strategy. Steps of data analysis and data coding system were also prepared to make the research and data analysis easier.

Result shows that the participant applied 13 of 16 socioaffective strategies. A good self-confidence and maturity make her be able to encourage herself to be sure of what she does. Student's taking emotional temperature strategy through taking risk wisely and cooperating with peers -as part of cooperating with others' strategy- seemed to be student's best preferences among others.
\end{abstract}

Keywords: strategy, socioaffective strategy, and reading

\section{INTRODUCTION}

Teaching and learning orientation has moved from traditional one - which puts attention on teachers' role and teaching method - to the learners' great involvement in the teaching learning process. How learners can maximize their 
own way to have better language learning is put on the priority. Appropriate language learning strategies will result proficiency and greater self-confidence. Many researches show that language students who apply strategies in learning have better result than those who do not. Learners who use strategies know what they have to do to overcome specific language task, they become self-directed learners inside or even outside the class.

This study focus only on socio-affective strategies which cover how the students used situation around them to deal with their problems and how they organize emotions, attitude and values in learning English language while motivating themselves in the process of language learning, especially in reading English text, because the writing on IT, as well as information and technology itself, has grown and there are so many articles about IT are released everyday in English, both in printing form and when students browse on the net.

Language learning strategies are classified into two classes: direct and indirect strategies. Direct strategies involve the target language (i.e. memory strategies, cognitive strategies, and compensation strategies), while indirect strategies do not involve the target language directly but they support and manage language learning (Oxford, 1990). Indirect strategies are divided into metacognitive, social, and affective strategies. This study highlights the last two strategies: social and affective strategies, later called socio-affective strategies applied by students in reading English text.

\section{LITERATURE REVIEW}

\section{Language Learning Strategy}

The concept of learning strategy depends on the assumption that learners consciously engage in activities to achieve certain goals and learning strategies can be regarded as broadly conceived intentional directions and learning techniques (Stern 1992: 261). All language learners use language learning strategies either consciously or unconsciously when processing new information and performing tasks in the language classroom. Since language classroom is like a problemsolving environment in which language learners are likely to face new input and difficult tasks given by their instructors, learners' attempts to find the quickest or easiest way to do what is required, that is, using language learning strategies is inescapable. In the same way, Oxford (1990: 8) defines learning strategies as 
specific actions taken by the learners to make learning easier, faster, enjoyable, more self-directed, more effective, and more transferable to new situations. These strategies stimulate the growth of communicative competence in general.

O'Malley et al. (1985: 582-584) divide language learning strategies into three main areas. The first one is metacognitive strategy, which covers planning for learning, thinking about the learning process as it is taking place, monitoring of one's production or comprehension, and evaluating learning after an activity is completed. Next is cognitive strategy that involves repetition, resourcing, translation, grouping, note taking, deduction, recombination, imagery, auditory representation, key word, contextualization, elaboration, transfer, and inferencing as the most important strategies. The last one is socioaffective strategy that deals with social-mediating activity and transacting with others, such as cooperation and question for clarification.

Rubin (1987), who pioneered much of the work in the field of strategies, makes the distinction between strategies contributing directly to learning and those contributing indirectly to learning. According to Rubin, there are three types of strategies used by learners that contribute directly or indirectly to language learning. The first type is learning strategy that deals with cognitive and metacognitive strategies. Cognitive refers to the steps or operations used in learning or problem-solving that require direct analysis, transformation, or synthesis of learning materials; it covers clarification/verification, guessing/inductive inference, deductive reasoning, practice, memorization, and monitoring. Metacognitive strategy is used to oversee, regulate, or self direct language learning; it involves various processes as planning, prioritizing, setting goals, and self-management. The second type is communication strategy, which is used by speakers when faced with some difficulty due to the fact that their communication ends out run their communication means or when confronted with misunderstanding by a co-speaker. It is more on the process of participating in a conversation and getting across or clarifying the conversation. The last type of Rubin is social strategy that related to activities engaging the learners to be exposed and practice their knowledge. Rubin and Wenden (1987:23-27) agree that although this strategy provides exposures to the target language, it contributes indirectly to learning since it does not lead directly to the obtaining, storing, retrieving, and using of language. 
Oxford (1990: 9) sees the aim of language learning strategies as being oriented towards the development of communicative competence. Oxford divides language learning strategies into two main classes, direct and indirect, which are further subdivided into 6 groups. The first three strategies included in direct strategy are memory strategies, cognitive strategies, and compensation strategies; while metacognitive strategies, affective strategies, and social strategies belong to indirect strategy. As described by the following figure, the extensions of the six strategies give a picture how Oxford (1990: 16-21) has classified it comprehensively.

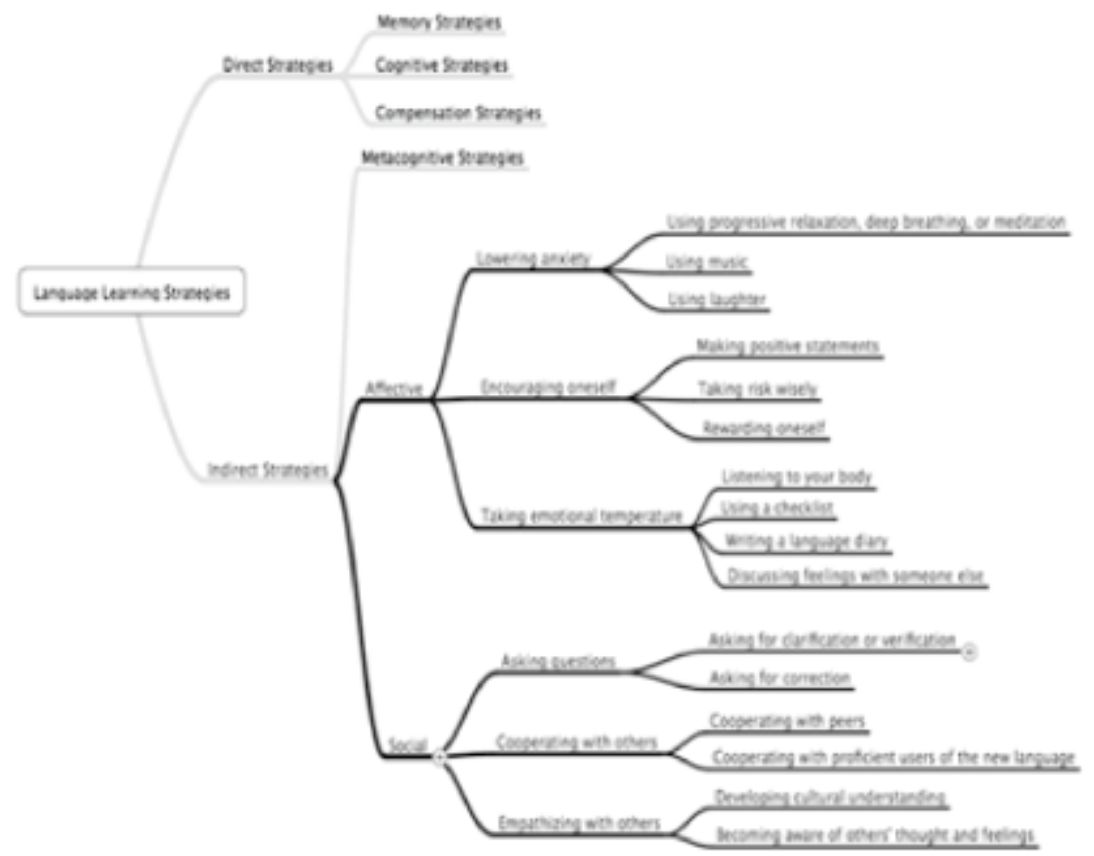

Figure 1 Oxford's Classification of Language Learning Strategy (1990) 


\section{Socioaffective Strategy in Reading Comprehension}

Language is a form of social behavior; it is communication, and communication occurs between and among people. Learning a language, thus involves other people and appropriate social strategies are very important in this process. Social strategies are those activities learners engage in which afford them opportunities to be exposed to and practice their knowledge. Although these strategies provide exposure to the target language, they contribute indirectly to learning since they do not lead directly to the obtaining, storing, retrieving, and using of language (Rubin and Wenden, 1987: 23-27).

While Stern (1992) said that students can use techniques in communication strategies such as circumlocution, gesturing, paraphrase, or asking for repetition and explanation to avoid interrupting the flow of communication, Oxford (1990: 145-147) describes it more details as three sets of social strategies, they are: 1 . asking question involving asking someone, possibly a teacher or native speaker or even a more proficient fellow learner, for clarification, verification, or correction; 2. cooperating with others which involves interacting with one or more people to improve language skills; and 3. empathizing with others which involves developing cultural understanding and becoming aware of others thoughts and feelings.

Oxford (1990: 9) sees affective strategies are concerned with the learner's emotional requirements such as confidence, while social strategies lead to increased interaction with the target language. The term affective refers to emotions, attitudes, motivations, and values. It is impossible to overstate the importance of the affective factors influencing language learning. Language learners can gain control over these factors through affective strategies. Three main sets of affective strategies are lowering one's anxiety, encouraging one's-self, and taking one's emotional temperature. The affective side of the learner is probably one of the very biggest influences on language learning success or failure. Good language learners are often those who know how to control their emotions and attitudes about learning. Negative feelings can inhibit progress, even for the rare learner who fully understands all the technical aspects of how to learn a new language. On the other hand, positive emotions and attitudes can make language learning far more effective and enjoyable.

Oxford (1990: 143-144) states that there are many ways to get affective strategies. In lowering anxiety there are three anxiety-reducing strategies, each has 
a physical component and mental component: 1. using progressive relaxation, deep breathing, or meditation, 2. using music, 3. using laughter. In encouraging oneself, there are three ways can be taken: 1. making positive statements, 2 . taking risk wisely, 3. rewarding oneself. In taking emotional temperature, learner can use listening to his body, using a checklist, writing a language learning diary, and discussing feelings with someone else.

O'Malley et al. (1985: 582-584) said that as to the social/affective strategies, it can be stated that they are related with social-mediating activity and transacting with others. Cooperation and question for clarification are the main social/affective strategies. Malley and Chamot (1990: 45) stated that social/affective strategies represent a broad grouping that involves either interaction with another person or ideational control over affect. The strategies that can uses are: 1. cooperation, or working with peers to solve a problem, pool information, check notes, or get feedback on a learning activity, 2. questioning for clarification, or eliciting from a teacher or peer additional explanation, rephrasing, or examples, 3. self-talk, or using mental control to assure oneself that a learning activity will be successful or to reduce anxiety about a task. Social/affective strategies concern the ways in which learners choose to interact with other speakers (Ellis, 1997: 77)

Since the amount of information to be processed by language learners is high in language classroom, learners use different language learning strategies in performing the tasks and processing the new input they face. Language learning strategies are good indicators of how learners approach tasks or problems encountered during the process of language learning. In other words, language learning strategies, while non-observable or unconsciously used in some cases, give language teachers valuable clues about how their students assess the situation, plan, select appropriate skills so as to understand, learn, or remember new input presented in the language classroom.

Socioaffective strategies include asking native speakers to correct their pronunciation, or asking a classmate to work together on a particular language problem. Lessard-Clouston (1997: 3) states that language learning strategies contribute to the development of the communicative competence of the students. Oxford (1990:1) describes language learning strategies as important tools of language learning because they are tools for active, self-directed movement, which is essential for developing communicative competence. Teachers who train 
students to use language learning strategies can help them become better language learners; and helping students understand good language learning strategies and training them to develop and use such good language learning strategies can be considered to be the appreciated characteristics of a good language teacher (Lessard-Clouston, 1997: 3). Degree of awareness, learning stage, task requirements, teacher expectations, age, sex, nationality/ethnicity, learning style, personality traits, motivation level, purpose for learning and the language itself give influences to students' successfulness.

Learning strategies can be taught. They are teachable and the main concern of this work is strategy training that can be considered as an essential part of language education. The flexibility of learning strategies gives students free access to choose, combine, and sequence the strategies in their own way; it is not always found predictable sequences or in precise patterns. Even in some cases, such as reading a passage, learners use some strategies in a predictable way, for example learners first preview the text by skimming or scanning, then read it more closely by using guessing, and the like.

In fact, learning strategies are not always observable to the human eye. For example, while many aspects of co-operating with someone else to achieve a learning goal are observable, it is impossible to observe a learner's act of making mental associations. Learning strategies are often conscious, for most of them are conscious efforts of learners to take control of their learning.

\section{Reading Skill}

Most of articles found about reading discuss reading comprehension cognitively because reading is about understanding written texts and it is a complex activity that involves both perception and thought. It consists of two related processes: word recognition, which refers to the process of perceiving how written symbols correspond to one's spoken language, and comprehension, which is the process of making sense of words, sentences and connected text. Readers typically make use of background knowledge, vocabulary, grammatical knowledge, experience with text and other strategies to help them understand written text. In general, skilled readers are able to construct meaning through the integration of existing and new knowledge and use certain strategies to assist, monitor, regulate, and maintain their comprehension (Grow, 1996). 
Learning to read is an important educational goal. It enables learners to find and explore new knowledge, enjoy literature, and do everyday things that are part and parcel of modern life, such as, reading the newspapers, job listings, instruction manuals, maps and so on. In this sense, then, we may assume that there are some communicative purposes on the writer's part, in which the reader is expected to attempt an understanding (Wallace, 1992).

Reading is very important in university life. Learners cannot expect teachers much to feed them with everything they need to do and think. So learners have to extend their initiative to get whatever they need to be successful learners. Yet, some of them do not like to read, while there will always something to do with the subject taken to read. Some of them get initiatives not to get lost of their confusing world, but some of learners do not know what to do. When they do not react properly to the text, it doesn't mean they do not care of it but they just do not know what to do. Then, it is the teacher who should show them the way to explore the strategy to accomplish their problems.

\section{Socioaffective Strategy in Reading}

Learners have to realize or at least they have to be led to realize that commitment to doing the work is the most crucial thing in university life. It directly motivates them to strengthen their attitude in learning rather than staying with their avoidance tactics.

Oxford's taxonomy (1990) clearly classifies learning strategy which can be used as a guide line to explore the socioaffective strategies on reading. Hosenfeld (1977 and 1984) found in his series of studies that less successful learners might be helped by looking at what good learners do. Choi (2003) found that the number of correctly translated clauses and words increased along with the rise of socioaffective strategic frequent use. This study also indicates that the interaction makes the negotiation get longer.

The use of socioaffective strategies in a reading class is based on the two theoretical backgrounds: the Interaction Hypothesis and the Sociocultural Theory. Socioaffective strategies, identified as learning strategies by O'Malley, Chamot, Stewner-Manzanares, Russo and Kuper (1985) and as communication strategies by Oxford (1990), have been further studied by those researchers working on the Interaction Hypothesis (Ellis, 1999). The Interaction Hypothesism which is 
interested in negotiation of meaning, has examines how speakers, both native and non-native, repair breakdowns in communication and how L2 learners learn second language through the process of interaction with others. The strategic features used to negotiate meaning include confirmation checks, clarification request, comprehension checks, repetitions, reformulation, and the like. These features help students modify the ways in which positive and negative evidences are given and thus better understand what they are learning and talking.

The key construct in the Sociocultural Theory is mediation of language by which students interact and cooperate to negotiate meaning and to communicate (Adair-Hauck \& Donato, 1994; Vygotsky, 1978). The sociocultural theory view such an interaction as a learning site where an expert can provide a novice with scaffolding that helps him/her to perform a task beyond the level of his current ability. The sociocultural researcher report the importance and effects of those features as tools which are used by the students to monitor their activities, recognize their problem, maintain shared perspective of the task, construct scaffolded helps, and thus enable themselves to complete their work.

One role of teacher is to judge how and when his or her own interventions might support an early reader when reading aloud. Thus, rather than simply 'hearing learners read' and focusing on how they pronounce the words, teacher and learners might profit from sharing their knowledge of particular topics and discussing the salient features of particular genres in the actual course of reading (Wallace, 1992: 61). These indirectly encourage learners to verify and clarify what they do not understand about the text, while lift their spirit to reduce their anxiety.

Since learners cannot expect teachers much to watch over them with everything they need to do and think, learners have to extend their initiative to get whatever they need to be successful learners and be aware of learning strategies to solve their problems. Socioaffective strategy is one of some learning strategies described by Oxford (1990) that can help learners to handle learners' problem. The Interaction Hypothesis and the Socialcultural Theory are the prime theories in this project. The Interaction Hypothesis, which is interested in one kind of interaction that is the negotiation of meaning, shows how speakers repair failures in communication and how L2 learners apply the process of interaction with others when they learn second language.

Following table is presenting the conceptual framework that summarizes the main constructs underlining the study. 
Table 1 Research construct and their operational definitions

\begin{tabular}{|c|c|c|c|}
\hline Construct & Concept & Categories & Indicators \\
\hline \multirow{6}{*}{$\begin{array}{l}\text { Reading } \\
\text { The process of } \\
\text { decoding words in } \\
\text { written or printed } \\
\text { form }\end{array}$} & \multirow{6}{*}{$\begin{array}{l}\text { Reading Comprehension } \\
\text { The process of drawing } \\
\text { information from a text and } \\
\text { integrating the information } \\
\text { with the existing knowledge } \\
\text { in order to understand the } \\
\text { text }\end{array}$} & \multirow[t]{3}{*}{$\begin{array}{l}\text { Linguistic } \\
\text { Processes }\end{array}$} & $\begin{array}{l}\text { Recognizing and } \\
\text { assigning meaning } \\
\text { to words }\end{array}$ \\
\hline & & & $\begin{array}{l}\text { Recognizing basic } \\
\text { relationship } \\
\text { between words }\end{array}$ \\
\hline & & & $\begin{array}{l}\text { Combining and } \\
\text { integrating word } \\
\text { meaning and } \\
\text { structural } \\
\text { information } \\
\end{array}$ \\
\hline & & \multirow[t]{3}{*}{$\begin{array}{l}\text { Comprehension } \\
\text { Processes }\end{array}$} & $\begin{array}{l}\text { Organizing the } \\
\text { main and } \\
\text { supporting ideas of } \\
\text { the text }\end{array}$ \\
\hline & & & $\begin{array}{l}\text { Interpreting the text } \\
\text { based on personal } \\
\text { feeling, goal, and } \\
\text { background } \\
\text { expectations }\end{array}$ \\
\hline & & & $\begin{array}{l}\text { Using relevant } \\
\text { strategies to assist, } \\
\text { repair, and } \\
\text { maintain } \\
\text { comprehension }\end{array}$ \\
\hline \multirow{6}{*}{$\begin{array}{l}\text { Reading Strategy } \\
\text { Conscious } \\
\text { decisions taken to } \\
\text { overcome problems } \\
\text { arising during } \\
\text { reading }\end{array}$} & \multirow{6}{*}{$\begin{array}{l}\text { Socioaffective Strategy } \\
\text { Learners involvements } \\
\text { either in interaction with } \\
\text { another person or ideational } \\
\text { control over affect. }\end{array}$} & \multirow[t]{2}{*}{$\begin{array}{l}\text { Asking } \\
\text { Questions }\end{array}$} & $\begin{array}{l}\text { Asking for } \\
\text { clarification or } \\
\text { verification }\end{array}$ \\
\hline & & & $\begin{array}{l}\text { Asking for } \\
\text { correction }\end{array}$ \\
\hline & & \multirow[t]{2}{*}{$\begin{array}{l}\text { Cooperating } \\
\text { with Others }\end{array}$} & $\begin{array}{l}\text { Cooperating with } \\
\text { peers }\end{array}$ \\
\hline & & & $\begin{array}{l}\text { Cooperating with } \\
\text { proficient users of } \\
\text { the new language }\end{array}$ \\
\hline & & \multirow[t]{2}{*}{$\begin{array}{l}\text { Empathizing } \\
\text { with others }\end{array}$} & $\begin{array}{l}\text { Developing } \\
\text { Cultural } \\
\text { understanding } \\
\end{array}$ \\
\hline & & & $\begin{array}{l}\text { Becoming aware of } \\
\text { others thought and } \\
\text { feelings }\end{array}$ \\
\hline
\end{tabular}




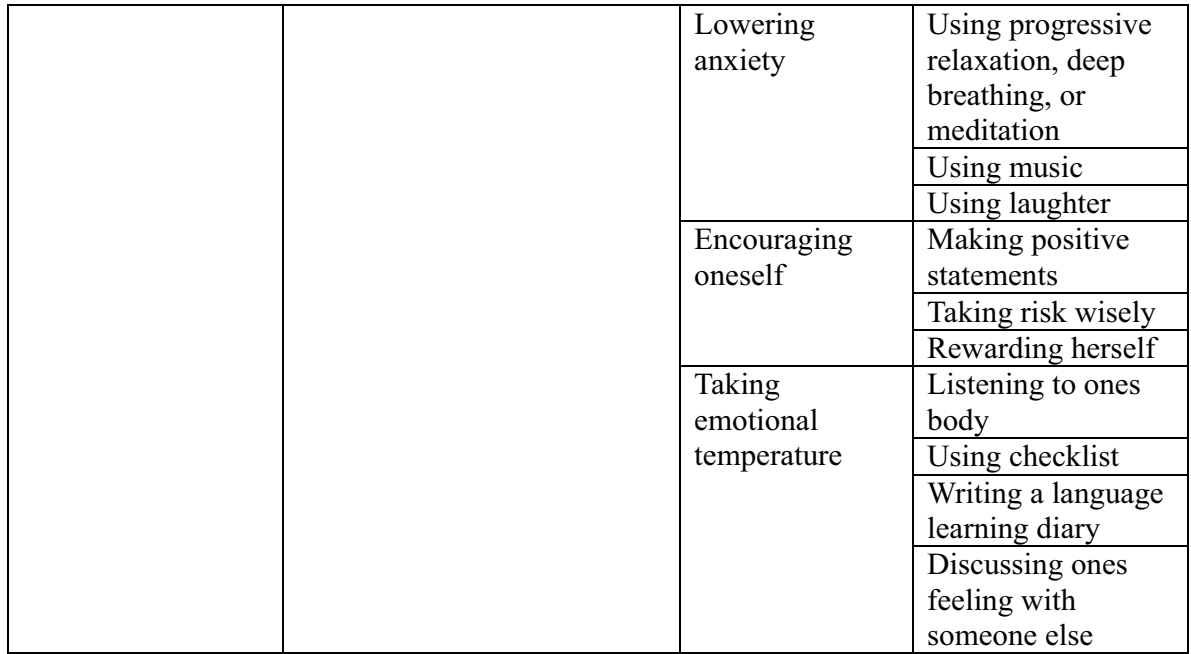

Through observation, reading and learner's diary documentation as well as interview, a pattern expectantly would gain the whole pattern of socio-affective strategy. The following figure explains the framework of the research.

Figure 2 The Framework of the Research

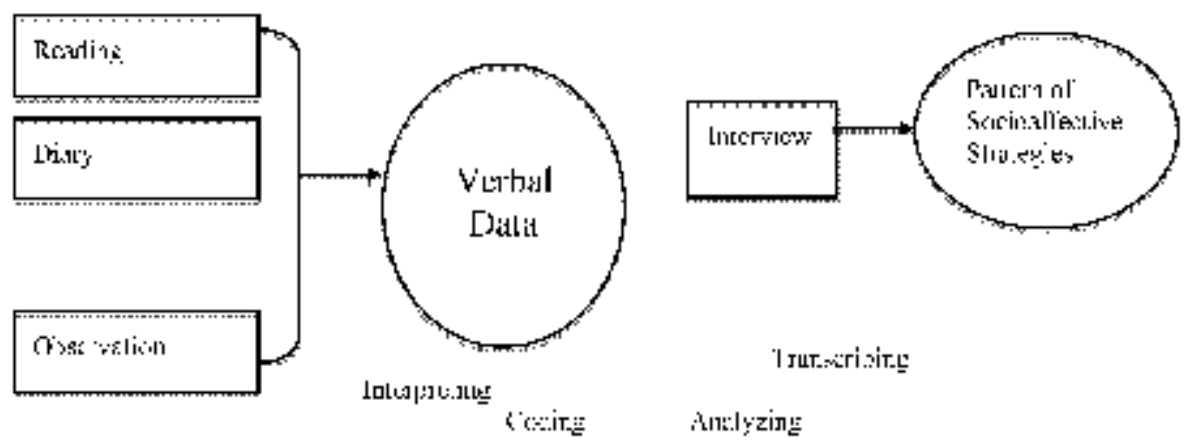




\section{METHOD OF STUDY}

This research is a progressive qualitative one in which the researcher illustrates the participant as the social world and constructing the social world through participant's interpretation of it, Hammersley and Atkinson in Holliday (2002). Besides, this research is fundamentally interpretive and some aspects possibly emerge during this study. It also seeks for involvement of the participants in data collection.

The inquiry strategy of this study is case study. Refer to Stake (1995) cited in Creswell (2003: 15), case study is a study in which the researcher explores in depth a program, an event, an activity, a process, or one or more individuals. The case is bounded by time and activity, and researcher collects detailed information using a variety of data collection procedures over a sustained period of time. The strategy would shapes the types of questions asked questions that relate to strategies; the form of data collection, the steps of data analysis, and the final narrative.

Some approaches to data recording, which are taken from Creswell (2003: 189-190), were done during this study. First, an observational protocol was used for observational data recording. It contains descriptive notes (portraits of the participants, a reconstruction of dialog, a description of the physical setting, accounts of particular events, or activities) and reflective notes (researcher's personal thoughts, such as speculation, feelings, problems, ideas, hunches, impressions, and prejudices" (Bogdan \& Biken, 1992: 121 as cited from Creswell, 2003: 189). As additional information, demographic information regarding time, place, and date of the field setting are added.

Next, a reading text on a certain topic, which was closed to participant's education life, was given to the participant to grab her understanding on a text. A recording equipment was also used to record data from interview. Finally, the participant was asked to keep a diary during the research and she could write everything she wanted to share with regarding reading difficulties and how she coped it, which might be missed to tell during the interview. Table 2 shows the general blueprint of the interview items: 
Table 2 Blueprint of the Interview Items

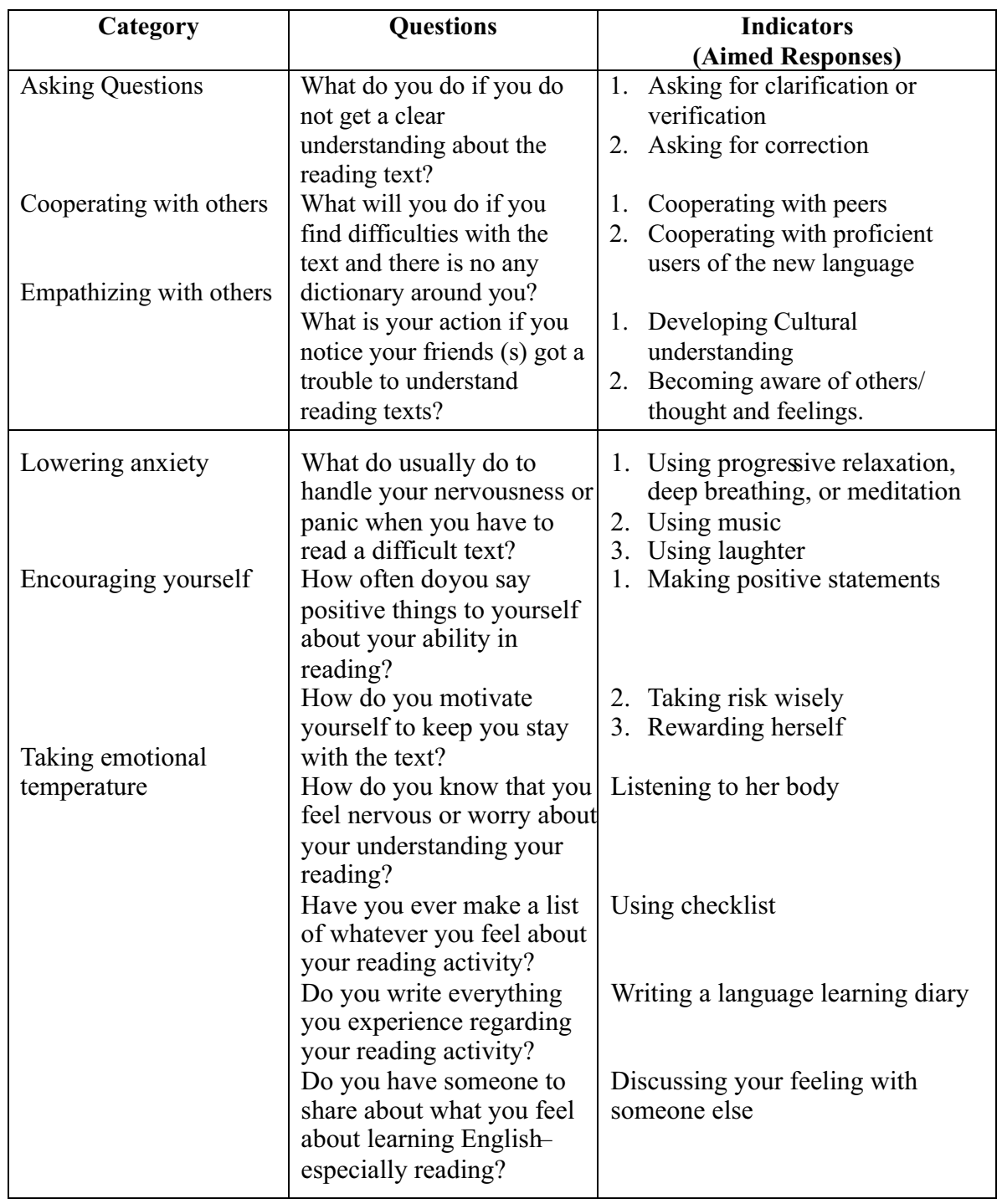




\section{RESULT AND ANALYSIS}

Both data collection and data analysis are in the same on going process and done successively, they cannot be strictly separated. Data analysis involves the following steps adopted from Creswell (2003: 191-195) are organizing and preparing the data for analysis, reading the data, and analyzing data in detail with a coding process, which mostly involved segmenting sentences into categories, and labeling those categories with a term. What follows in table 3 listing the final data coding system, including the emergent indicators, used in this study.

Table 3 The Data Coding System

\begin{tabular}{|c|c|c|c|}
\hline Theme & Category & Indicators & Code \\
\hline \multirow{16}{*}{$\begin{array}{l}\text { Socioaffective } \\
\text { Strategy }\end{array}$} & \multirow[t]{2}{*}{ Asking Questions } & $\begin{array}{l}\text { Asking for clarification or } \\
\text { verification }\end{array}$ & ASQ-ACV \\
\hline & & Asking for correction & ASQ-COR \\
\hline & \multirow{2}{*}{$\begin{array}{l}\text { Cooperating with } \\
\text { others }\end{array}$} & Cooperating with peers & COP-PER \\
\hline & & $\begin{array}{l}\text { Cooperating with proficient users of } \\
\text { the new language }\end{array}$ & COP-PUS \\
\hline & \multirow{2}{*}{$\begin{array}{l}\text { Emphatizing with } \\
\text { others }\end{array}$} & Developing cultural understanding & EMP-DCU \\
\hline & & $\begin{array}{l}\text { Becoming aware of others thought } \\
\text { and feelings }\end{array}$ & EMP-ATF \\
\hline & \multirow[t]{3}{*}{ Lowering anxiety } & $\begin{array}{l}\text { Using progressive relaxation, deep } \\
\text { breathing, or mediation }\end{array}$ & LAN-LAX \\
\hline & & Using music & LAN-MUS \\
\hline & & Using laughter & LAN-LAU \\
\hline & \multirow{3}{*}{$\begin{array}{l}\text { Encouraging } \\
\text { oneself }\end{array}$} & Making positive statement & ENC-POS \\
\hline & & Taking risk wisely & ENC-TRW \\
\hline & & Rewarding oneself & ENC-REW \\
\hline & \multirow{4}{*}{$\begin{array}{l}\text { Taking emotional } \\
\text { temperature }\end{array}$} & Listening to ones body & TET-LTB \\
\hline & & Using Checklist & TET-UCL \\
\hline & & Writing a language learning diary & TET-WLD \\
\hline & & $\begin{array}{l}\text { Discussing feelings with someone } \\
\text { else }\end{array}$ & TET-DFO \\
\hline
\end{tabular}

By using the data coding system, the coded data from single participant's interview and protocol transcripts were summarized and assigned to categories to see their similarities as well as differences. The summarized and organized main features of the data are generated into a description of the participant as well as categories and themes for analysis. 
Presenting the analysis in qualitative narrative form in which this step involves visual, figures, and tables as descriptive information about participant, while making an interpretation is the final step of data analysis. It is researcher's personal interpretation and understanding that the inquirer brings to the study from participant's own culture, history, and experience.

In the following table (Table 4), steps of data acquisition and analysis activities are summarized to make it easier to see the activities as a whole one.

\section{Table 4 Steps of Data Acquisition and Analysis Activities}

\begin{tabular}{|c|c|c|c|c|}
\hline Step & $\begin{array}{c}\text { Instrument/ } \\
\text { Method }\end{array}$ & Purpose & Result & Analysis \\
\hline 1. & $\begin{array}{l}\text { Classroom } \\
\text { Observation }\end{array}$ & $\begin{array}{l}\text { 1. To find one who can be } \\
\text { taken as a participant of the } \\
\text { research. } \\
\text { 2. To get the initial data of the } \\
\text { participant }\end{array}$ & Notes & $\begin{array}{l}\text { Observed } \\
\text { members of } \\
\text { the class who } \\
\text { is the most } \\
\text { active one. }\end{array}$ \\
\hline 2. & Reading text & & & \\
\hline 3. & $\begin{array}{l}\text { Interview } \\
\text { (based on } \\
\text { blueprint) }\end{array}$ & $\begin{array}{l}\text { To get a whole picture of } \\
\text { participants socioaffective } \\
\text { strategy in reading. }\end{array}$ & $\begin{array}{l}\text { 1. Recorded } \\
\text { verbatim data } \\
\text { 2. Notes }\end{array}$ & $\begin{array}{l}\text { Transcribed } \\
\text { and coded } \\
\text { into a table }\end{array}$ \\
\hline 4. & Diary & $\begin{array}{l}\text { To gain more information } \\
\text { which possibly have not been } \\
\text { informed to the researcher. }\end{array}$ & $\begin{array}{l}\text { Personal } \\
\text { document }\end{array}$ & $\begin{array}{l}\text { Confirming } \\
\text { the previous } \\
\text { finding. }\end{array}$ \\
\hline 5. & $\begin{array}{l}\text { Transcripts of } \\
\text { coded data from } \\
\text { the first interview }\end{array}$ & $\begin{array}{l}\text { To make tables of participants } \\
\text { personal accounts based on the } \\
\text { transcript of the coded data of } \\
\text { the participant. }\end{array}$ & $\begin{array}{l}\text { Table of } \\
\text { personal } \\
\text { accounts of the } \\
\text { participant }\end{array}$ & $\begin{array}{l}\text { Analyzed to } \\
\text { get the verbal } \\
\text { description of } \\
\text { the personal } \\
\text { accounts }\end{array}$ \\
\hline 6. & $\begin{array}{l}\text { Re-interview } \\
\text { (based on } \\
\text { previous } \\
\text { interview } \\
\text { transcription) }\end{array}$ & $\begin{array}{l}\text { 1. To get a confirmation on } \\
\text { coding system and the result } \\
\text { of previous interview. } \\
\text { 2. To gain more information } \\
\text { related to the finding and } \\
\text { correlation of each fact } \\
\text { found. }\end{array}$ & $\begin{array}{l}\text { Recorded } \\
\text { verbatim data }\end{array}$ & $\begin{array}{l}\text { Triangulation } \\
\text { (Analyzed } \\
\text { and } \\
\text { compared } \\
\text { recent } \\
\text { interview } \\
\text { with the } \\
\text { previous one, } \\
\text { reading text, } \\
\text { and diary) }\end{array}$ \\
\hline 7. & $\begin{array}{l}\text { Tables and verbal } \\
\text { descriptions of } \\
\text { the personal } \\
\text { accounts }\end{array}$ & \multicolumn{3}{|c|}{$\begin{array}{l}\text { The tables and verbal descriptions combined with the related } \\
\text { theories and the researchers views are analyzed in order to make } \\
\text { the interpretation of students socioaffective strategy in reading. }\end{array}$} \\
\hline
\end{tabular}


Triangulation is typically a strategy for improving the validity and reliability of research or evaluation of findings (Paton, 2002). In this study, researcher examined the data validity through observation and in depth interview using triangulation to provide confirmation and completeness. The interviews went through in-depth semi structures interviews intending for encouraging the student to be freer and more relax in giving any response to open-ended questions during previous interview and to personal diary or inquiries about strategies they apply when they are reading. By this way, interview also served to triangulate the data gathered from previous interview and student's diary.

Participant of this research was selected by observing an English lecturer peer's classes. She showed a good attitude toward the teaching and learning process in the class by being active in the class. The first interview focused on the socioaffective strategy that participant might use during reading, another one was more on the participant's past life and experiences compared to her present college life that possibly influenced her strategy options.

During the data collection process, the participant showed high selfconfidence and it made a bit hard at the beginning to find what should be found in her, because it seemed that she could handled her problem well even she herself did not sure the quality of the result. She preferred to use other strategies, which are not my concern. What follows is the sample showing her efforts without relying to others.

\author{
$\mathrm{R} \quad$ : Kalau gak ada kamus? \\ $\mathrm{S}$ : Ya pakai logika kali ya.. ooo, ini mungkin artinya ini... ada \\ kalimat pembanding juga atau kata-kata yang membantu untuk \\ mengartikan kata-kata yang gak dimengerti. (Ria Interview 1)
}

It might be caused by different circumstances between her past stage in senior high school and her previous life at college. She thought that it was more comfortable and more fun to learn English at senior high school rather than at college. It seemed that her senior high life was more competitive than present. She was more confident in doing reading herself and did not find any difficulty. Next quotation describes her independence. 


\section{R: Pernah gak, waktu nemu kesulitan membaca... di sekitar ada temen, kira-kira gimana...?
S: Kalau deket temen malah kayaknya gak deh, paling kalau pas sendiri baca-baca... (Ria-Interview 1)

It was also clearly noticed that what came to the participant's mind when she was asked about things she would do when she had problem in reading was always related to cognitive, which are resourcing (consulting on dictionary), elaboration (relating new information to other concepts in memory), and inference (using available items to guess meanings of new items, predict outcomes, or fill in missing information).

When she was asked about what she would do if she got problems in reading in her class and there was no dictionary, she showed to apply sorts of socioaffective strategies; asking for clarification and verification or she might coordinate with her teacher. She did not mention directly that she would ask her friends for help but I could catch that she meant it. In the class, it is very possible to find a very boring situation that can be caused by many things inside (feeling tired or sleepy) or outside the students (chilled air conditioner, disturbing friends, or the lecturer). She sometimes experienced a 'not in the mood' circumstance and she prefers to keep quiet as she knew that nothing could make her connected to the material. She could feel her feeling and decide what to do with that certain feeling. But when she thought nobody did ask, she would do ask for clarifying or verifying the problem. Sometimes she had her own prediction of her answer, but she still needed a confirmation from her lecturer to make sure that what she thought was right or still needed to be corrected. In this case, it could be seen that she applied a strategy called asking for correction. The next question was related to her thought and feelings when she knew that there were friends who seemed to have trouble in reading. She obviously stated that she would help her friends or vice versa, and she would not mind to cooperate with her friends.

In the first interview she gave a picture of her willingness to help her friends when they faced problems. In the second interview, participant stated whether she could see that her friends needed help or not, she said that she could see it. She was just not sure how to help them while themselves did not show their interest or attention to English. It meant the lack abilities and interest students did 
not show their initiative to ask when they feel confused, so she was in doubt about helping them. It really depended on her feelings. If she thought that 'the friends' are close enough with her, it would be alright for her to share everything she knew. But when she saw that 'the friends' are not really close and they seemed not to care about what happened during the class, she preferred not to say a word. She was afraid it would hurt them and it made them think that she showed off, while she herself realized that her English was also not that good. She tended to cooperate with peers who seemed to have the same interest in English. It showed her awareness to others' thought and feelings; even it did not make her help others instantly. It is probably not enough to be considered as a cultural understanding, but I can notice that she respected others' thought and feelings even she thought that she had to think twice to give them a hand.

Taking risk wisely is another interesting topic in this interview. It seemed to be her main option in order to handle her problem in reading As someone who had a good self confident, she really knew what to do to overcome her problems to avoid panic and stress due to limited time and load of work. Confusion, dizziness, and panic were very common for her life as a student. All she knew was trying to manage her time and 'reading' work, and doing the best even she knew that it had not been something perfect. She preferred to prepare herself before class in order to optimize her performance, do it step by step, and make a plan to avoid panic, feeling bored, or stressed. Besides, she tended to take a rest whenever she felt tired and did other things to make her relax before continuing reading.

It can also be seen that she preferred to take a recess whenever she felt tired or bored and continue reading after she relaxed herself. During the recess, she could go to a movie or look for another entertaining thing to reward herself. She also tended to take a rest when her eyes were tired before continuing reading. Even listening to music was one of her choices to relax during reading activity, she said that laying on her bed or checking emails were more interesting to do than listening to music.

To keep herself in a good mood, she sometimes told jokes with friends especially when she and friends were not really in to the material. It can be considered as her effort to lower her anxiety rather than being stressed due to a certain difficult task. She also always tried to raise her self-confidence by telling herself that she could do anything to make her calm down. This positive statement really helped her not to feel anxious. 
It was really appreciated that the participant, as a student, was able to keep her spirit on learning and her self-confidence. She knew what to do to her problems with everything she knew and had, and she knew when she had to do it; deciding when to stop and continue reading. She did not push herself whenever she thought she could not handle it more and she tried to do something else and then got back to her reading whenever she was ready. It means she could listen to her body and it made her decide what to do next. A slight conversation led to a better understanding that she did not hesitate to communicate her problems with someone who knows better, to cooperate with proficient users of the new language.

Compare to the first interview, the second one was more colorful. It did not only explore possibilities of her using of socioaffective strategies, but also about her self-confident. It is interesting to find that she could have such a good selfconfident. She explained that her senior high school time influenced her development in English. Even reading was not exposed as much as vocabulary; it really built her self-confidence as well as friends with good skills surrounded her. It did not mean that she could not find good English skilled friends at the college where she took course.

Whenever she got an assignment, she tried to solve it and when she could handle it, it made her feel better and then raise her self-confident. Later, when she found that her friends believed that she had a good ability in English, it also increased her such affective state. She added that her family never talked in English at home, so she just often practiced talking in English with her good friends.

Writing a language diary and using checklist are two strategies that seemed to be out of her mind. She was asked to write on her diary twice. The first one was supposed to be related to her reading activity and might have forgotten to be said at the first interview, while the second one was about herself. The fact that she did not have the habit of writing a language diary might be the reason why her first diary did not really help at all and it was decided not to include it as a document. She usually wrote something on the text paper directly to remind her what to ask to her teacher or friends. She made plans but it was not specifically about reading but English generally, so it is not considered as using checklist.

As the summary of all kinds of socioaffective strategies, which the participant used in reading, a table was provided as the guidelines to the discussion part attempting to the research question posed earlier in this thesis. Table 5 shows the summary of Ria's socioaffective strategies in reading. 


\section{Table 5 Summary of Ria's Socioaffective Reading Strategies}

\begin{tabular}{|c|c|c|c|}
\hline Theme & Category & Indicators & Action \\
\hline \multirow{16}{*}{$\begin{array}{l}\text { Socioaffective } \\
\text { Strategy }\end{array}$} & \multirow[t]{2}{*}{ Asking Questions } & $\begin{array}{l}\text { Asking for clarification } \\
\text { or verification }\end{array}$ & Asking clues to the teacher \\
\hline & & Asking for correction & $\begin{array}{l}\text { Communicating her prediction to } \\
\text { the teacher }\end{array}$ \\
\hline & \multirow[t]{2}{*}{$\begin{array}{l}\text { Cooperating } \\
\text { with others }\end{array}$} & $\begin{array}{l}\text { Cooperating with } \\
\text { peers }\end{array}$ & $\begin{array}{l}\text { Doing assignment with friends } \\
\text { Help one another to solve } \\
\text { problems }\end{array}$ \\
\hline & & $\begin{array}{l}\text { Cooperating with } \\
\text { proficient users of the } \\
\text { new language }\end{array}$ & $\begin{array}{l}\text { Communicating her problems to } \\
\text { the teacher } \\
\text { Communicating her problems } \\
\text { with friends who know better }\end{array}$ \\
\hline & \multirow[t]{2}{*}{$\begin{array}{l}\text { Emphatizing } \\
\text { with others }\end{array}$} & $\begin{array}{l}\text { Developing cultural } \\
\text { understanding }\end{array}$ & *) \\
\hline & & $\begin{array}{l}\text { Becoming aware of } \\
\text { others thought } \\
\text { feelings }\end{array}$ & $\begin{array}{l}\text { Being able to see what friends } \\
\text { thought and said. } \\
\text { Being able to feel what others } \\
\text { feel about English reading }\end{array}$ \\
\hline & \multirow[t]{3}{*}{$\begin{array}{l}\text { Lowering } \\
\text { anxiety }\end{array}$} & $\begin{array}{l}\text { Using progressive } \\
\text { relaxation, deep } \\
\text { breathing, or } \\
\text { mediation }\end{array}$ & $\begin{array}{l}\text { Trying to relax by attending a } \\
\text { movie or any other entertaining } \\
\text { form } \\
\text { Doing other things to refresh her } \\
\text { mind, such as checking e -mails, } \\
\text { making juices, watching TV, etc. }\end{array}$ \\
\hline & & Using music & $\begin{array}{l}\text { Sometimes reading while laying } \\
\text { back and listening to favorite } \\
\text { songs }\end{array}$ \\
\hline & & Using laughter & $\begin{array}{l}\text { Making jokes when something } \\
\text { wrong came up to break the } \\
\text { confusion. }\end{array}$ \\
\hline & $\begin{array}{l}\text { Encouraging } \\
\text { yourself }\end{array}$ & $\begin{array}{l}\text { Making positive } \\
\text { statement }\end{array}$ & $\begin{array}{l}\text { Make herself sure that she could } \\
\text { do it. }\end{array}$ \\
\hline & \multirow[t]{2}{*}{$\begin{array}{l}\text { Taking emotional } \\
\text { temperature }\end{array}$} & Taking risk wisely & $\begin{array}{l}\text { Doing the task slowly and } \\
\text { gradually. } \\
\text { Preparing herself before the class } \\
\text { and performing }\end{array}$ \\
\hline & & Rewarding herself & Doing anything like to do \\
\hline & & Listening to her body & $\begin{array}{l}\text { Feeling uncomfortable } \\
\text { Feeling dizzy when could not } \\
\text { find the answer of her own } \\
\text { question. } \\
\text { Panic when due date was ahead }\end{array}$ \\
\hline & & Using Checklist & $*)$ \\
\hline & & $\begin{array}{l}\text { Writing a language } \\
\text { learning diary }\end{array}$ & $*)$ \\
\hline & & $\begin{array}{l}\text { Discussing feeling } \\
\text { with someone else }\end{array}$ & $\begin{array}{l}\text { Sharing with a close friend who } \\
\text { felt the same. }\end{array}$ \\
\hline
\end{tabular}

*) socioaffective strategies not performed 


\section{CONCLUSIONS AND SUGGESTION}

This research aimed to reveal the pattern of socio-affective strategies in reading which the college student use and how the strategies facilitate better understanding of the text she is reading. There was only one student involved in this research and in order to identify the socio-affective strategies used, the student was interviewed a couple times about her experiences in reading and was asked to write a personal diary. The aim of writing diary was to add information which might not be stated or confirm the statements given in the interview session, but since there was not any verification regarding her problems in reading it was decided to eliminate the diary. The second student's note showed her personal background and it had nothing to do as well with how she coped her problems in reading unless the fact that it confirmed her affective state.

Analysis of the data gathered from the interviews and student's diary showed that the student applied 13 of 16 socio-affective strategies, about $81 \%$. It is quite impressive since it was weird for her to realize that some actions done during reading or other English activity were regarded as strategy. Using laughter for example, she thought it was merely something silly coming up when she got bored or sleepy. Then, she knew that it one of learning strategies to reduce bad feelings and open the access to reading.

Macintyre (1995) states that there is no doubt that anxiety can be provoked by having difficulty in learning the language, but that is not to conclude that anxiety plays no role in contributing to such difficulties in the first place. In this study, I saw that the students could facilitate her anxiety by having a break and continuing to read whenever she was ready. While having a break she could check emails, making juices, or even just laying on her bad. It made her able to perform better because she could refill her energy or spirit while having a break.

The student involved in this study had a very good self-confidence and it really influenced her performance in learning English. It gave her access to decide what to do to handle her problems. Through this research, it was proven that she had applied a great number of socio-affective strategies. Therefore, this research result could not be used to generalize all students' socio-affective strategies. The limitation of time during the study made the data gathered not thoroughly complete. 
Socio-affective strategies as parts of learning strategies are applied to make a better learning. As English teachers - it is very important to know what socioaffective strategy possibly and significantly borne by students. It will help teachers understand and evaluate better students' reading knowledge and how to teach them. It is very critical to understand that providing more opportunities and access to using socio-affective strategies would be beneficial to both teachers and students in the process of making learning and teaching enjoyable and successful. After identifying kinds of socio-affective strategies that students mostly used, teachers have the opportunity to build appropriate reading materials that will persuade students to use the strategies. It automatically will lead them to enjoy the reading and when they really have experienced enjoyable circumstances in reading, the ability of providing themselves with more enjoyable reading materials will gradually grow. There will no be hesitation in reading any kinds of reading and limit their reading only to their interests but also text specifically related to their study or work world. They do not have to wait for articles released in Indonesian printed form to get to know about something that crucially influence their study and work. Finally, it will give effects to their learners'- successfulness.

In the future, it is very recommended to involve more participants in this kind of research to see varieties socio-affective strategies applied by students. It might give a wider range of data, better result, and correspondingly extend the validity and reliability of the research. A clearer instruction on making students' diary and researcher's ability in extending open-ended questions must be more nurtured, so the data gathered are more comprehensive. While having a wider range of data will be beneficial for result, its validity, and reliability; it will provide information about differences might occur among the students. Further research will have opportunities to explore the factors that affect the students to use such socio-affective strategies.

In addition to interview and students' diary, I strongly recommend conducting observation since there are some socio-affective strategies can be revealed through observation to enrich the data and strengthen the validity of the result. 


\section{REFERENCES}

Adair-Hauck, B., \& Donato, R. 1994. Foreign language explanations within the zone of proximal development. The Modern Language Review, 50, 532557

Choi, K. 2003. A study on the effects of socioaffective strategies on reading comprehension. Journal of Pan-Pacific Association of Applied Linguistic (2003) Vol. 7 (1) retrieved May 29, 2010 from http://www.paaljapan.org/resources/proceedings/PAAL7/pdfs/05kyungh ee.pdf

.2005. A discourse analysis of Students' Interaction for Reading Comprehension. Journal of Pan-Pacific Association of Applied Linguistic (2005) Vol. 8 (2) retrieved May 29, 2010 from http://www.paaljapan.org/resources/proceedings/PAAL8/pdf/pdf005.pdf

Creswell, John W. 2003. Research design: Qualitative, quantitative, and mixed method approaches. $2^{\text {nd }}$ Edition. California: Sage Publication, Inc.

Ellis, Rod. 1997. Second Language Acquisition. Oxford: Oxford University. Press

Grow, Gerald O. 1996. Serving the strategic reader: reader response theory and its implications for the teaching of writing. An expanded version of a paper presented to the Qualitative Division of the association for Educators in Journalism and Mass Communication. Atlanta. August 1994. Retrieved January 23, 2008 from http://www.longleaf.net/ggrow/StrategicReader/StratModel.html

Holliday, A. 2002. Doing and Writing Qualitative Research. SAGE.

Hosenfeld, C. 1979. 'A preliminary investigation of the reading strategies of successful and nonsuccessful second language learners. System 2 (1979): 110-23

Lessard-Clouston, M. 1997. Language Learning Strategies: An overview for L2 teachers. Retrieved January 23, 2008 from http://iteslj.org/Articles/Lessard-Clouston-Strategy.html

Macintyre, P.D. 1995. How does anxiety affect second language learning? A reply to Sparks and Ganschow. The Modern Language Journal. 79.i. 9099 
O'Malley. J. and Chamot, A. U. 1990. Learning Strategies in Second Language Acquisition. Cambridge: Cambridge University Press.

O'Malley, J. M., \& Chamot, A. U., Stewner-Manazanares, G., Russo, R., \& Kupper, L. 1985. Learning strategy applications with students of English as a second language. TESOL Quarterly, 19, 557-584

Oxford, Rebecca. 1990. Language learning strategies: What every teacher should know. Boston: Hinle \& Hinle.

Patton, M.Q., 2002. Qualitative Reasearch and Evaluation Methods. $3^{\text {rd }}$ Edition. Thousand Oaks: Sage Publications.

Rubin, J. 1987. Learner strategie: Theoretical assumptions, research history, and typology. In A. Wenden \& J. Rubin. Eds. Learners Srtaregies and Language Learner. $2^{\text {nd }}$ Edition. Boston: Hinle \& Hinle.

Stern, H.H. 1992. Issues and Options in Language Teaching. Oxford: Oxford University Press.

Vygotsky, L. S. 1978. Mind in society: the development of higher psychological processes. Cambridge, MA: Harvard University Press.

Wallace, Catherine. 1992. Reading. Oxford: Oxford University Press. 


\section{Writers Biography}

Journal of English and Education, Vol. 6 No. 1 Juni 2012

Astri Hapsari accomplished her bachelor degree in English Literature at STBA Prayoga Padang, West Sumatera in 2009. She enjoys reading both canonical and modern literature as her favourite activity in spare time. In 2012, she completed her Master of TESOL (M.TESOL) from The University of Melbourne.

Dwiyani Pratiwi is the lecturer of English Education Department, Faculty of Languages and Arts, Yogyakarta State University. She got her S.Pd (Sarjana Pendidikan) from Yogyakarta State University in 2001, and she earned her master degree on Language Teaching from Postgraduate Program, Yogyakarta State University in 2004. Her professional and academic interests are on the students' learning strategies and language teacher education.

Fauzul Aufa is a full-time postgraduate student at University of Queensland majoring Applied Linguistics under Australian Development Scholarship (ADS). Prior to being one of ADS awardees, Aufa was a Teaching Assistant (TA) in English Department of State University of Padang, Indonesia, from 2008 to 2011. Having graduated from the same university with B.Ed. in English Teaching, he started teaching Computer Assisted Language Learning (CALL), Language Testing, and Interpretation course

Ista Maharsi is an English lecturer at Islamic University of Indonesia, Yogyakarta. She earned her bachelor degree from Diponegoro University in Semarang and her Master degree from Sanata Dharma University Yogyakarta. She has taught English for undergraduate students of Industrial Engineering, Economics, and Diploma 3 English Program. Her current research interests are classroom practices, learning experiences, English for Specific Purposes, academic writing, academic reading, and translation. 